\title{
Biodiesel Production Utilizing Diverse Sources, Classification of Oils and Their Esters, Performance and Emission Characteristics: A Research
}

\author{
Mohamed Kafeel Delvi, Manzoore Elahi M Soudagar, Hurmathulla Khan, Zahoor Ahmed \\ Shariff, Imran Mokashi
}

\begin{abstract}
The ever increasing utilization of energy has resulted in the nation becoming progressively more dependent on fossil fuels such as oil, coal and gas. The mounting prices of crude oil and natural gas and their impending paucity have raised qualms about the security of energy supply in future, which has severe consequence on the augmentation of a countries economy. The alternative to fossil fuels are the nonconventional energy sources, they are plentiful, renewable, pollution-free and eco-friendly. Therefore, the need to utilize renewable energy sources like solar energy, wind, tide, biodiesel has publicized its significance. Biodiesel is one of the unsurpassed resources that have come to the cutting edge recently. In this article, highly rated research journals on biofuels were referred and a detailed assessment has been conducted to emphasize different aspects to biodiesel engineering. These aspects include biodiesel feed stocks, a range of various methods used in production of biodiesel such as pyrolysis, micro emulsion, dilution and transesterification (alcoholysis). The study was extended to understand the effect of biodiesel blend magnitude on the performance of engine parameters such as brake power (BP), brake thermal efficiency (BTE) and fuel properties like cloud point, flash point, calorific value, kinematic viscosity, density, and cetane number as well as the economic viability, emission characteristics and finally Greenhouse gas emissions.
\end{abstract}

Keywords-Edible feedstock oil, Non Edible Feedstock oil, Viscous properties, Efficiency $\mathrm{O} 2, \mathrm{CO} 2, \mathrm{CO}$ and Hydrocarbon .

\section{INTRODUCTION:BIODIESEL FEEDSTOCK}

Biodiesel fuel is one of the simplest and easiest replacing fuels to utilize. A diversity of oils as biodiesel fuel feed stocks are used to produce the fuel. Across the world, there are more than 300-350 oil-bearing harvest known for huge sources of biodiesel production [1,9,11,22,29,44,50-59]. The abundance availability of feed stocks for biodiesel production one of the significant factors in producing biodiesel. The feedstock should possessed two main

Revised Manuscript Received on July 10, 2019

Mohamed Kafeel Delvi, Department of Mechnical Engineering, Bearys institute of technology Manglore, Karnataka,India. (rulerkafeel@yahoo.co.in)

Manzoore Elahi M Soudagar, Department of Mechanical Engineering, Faculty of Engineering : University of Malaya 50603 Kuala Lumpur, Malaysia.(me.soudagar@gmail.com)

Hurmathulla Khan, Department of Mechanical Engineering, HMS Institute of Technology Tumkur, India. (hurmath1980@gmail.com)

Zahoor Ahmed Shariff, Department of Mechanical Engineering, HMS Institute of technology Tumkur, India. (zahoorshariff146@gmail.com)

Imran Mokashi, Department of Mechanical Engineering, Faculty of Engineering, Inetrernational Islamic University, Malaysia. (mokashi782@gmail.com) parameter: production cost should be low and production scale should be large. For a high-quality yield of high oil bearing it should satisfy geographical locations, the regional climate, agricultural practices and local soil conditions of any country. The conventional and non-conventional feedstock used for the production of biodieselis listed in TABLE 1.These includes edible oils, non-edible oils, waste vegetable oil, animal fats and Oil from halophytes. The most common edible oil and non-edible oils are palm, canola rapeseed, mustard, sunflower, Jatropha, soybean, cottonseed, corn, jojoba oils, olive, coconut, hazelnut, honge pistachio, Neem, sesame, mahua, linseed, and castor[1-5, 9]. According to topography Soybean oil is usually utilized in the USA, rapeseed oil used in European countries, palm oil used in Malaysia, and Jatropha and honge oils are eaten by Indian [11]. TABLE 2 shows primary biodiesel feedstock for few countries around the world. Biodiesel is long-chain fatty acids made up of mono-alkyl esters derivative of animals fats or vegetable oils. In layman's terms, it is a clean-burning substitute fuel made from animal fat or vegetable oil which is chemically processed to remove glycerin. Biodiesel is commonly prepared from non edible lignocelluloses biomass and is the second generation fuel. Biodiesel in pure form refers to the unmodified fuel known as B100 which has been recognized as a substitute fuel by the U.S. Departments of Energy and Transportation. B100 can be utilised in its pure condition, but in general it is used as an additive for diesel fuel. [46,51,52]

TABLE 1. Main feed stocks of biodiesel [1, 9$18,25,36,42,44,49]$

\begin{tabular}{|l|l|}
\hline Groups & Source of oil \\
\hline Edible & $\begin{array}{l}\text { Soybeans (Glycine max),Safflower, Rice bran } \\
\text { oil (Oryza sativa), Barley, Sesame (Sesamum } \\
\text { indicum L.), Groundnut, Sorghum, Wheat, } \\
\text { Corn, Coconut, Canola, African oil palm } \\
\text { (Elaeisguineensis), Sunflower (Helianthus } \\
\text { annuus) ,Rapeseed (Brassica napus L.) }\end{array}$ \\
\hline
\end{tabular}




\section{BIODIESEL PRODUCTION UTILIZING DIVERSE SOURCES, CLASSIFICATION OF OILS AND THEIR ESTERS, PERFORMANCE AND EMISSION CHARACTERISTICS: A RESEARCH}

\begin{tabular}{|c|c|}
\hline $\begin{array}{l}\text { Non edil } \\
\text { oil }\end{array}$ & $\begin{array}{l}\text { etton seed (Gossypium hirsutum), Jatropha } \\
\text { curcas, Pongamia (Pongamiapinnata), } \\
\text { Pongamia (Camelina Sativa), Karanja or } \\
\text { honge (Pongamiapinnata), Cumaru, Cynara } \\
\text { cardunculus, Mahua (Madhucaindica), Coffee } \\
\text { ground (Coffea Arabica), Abutilon muticum, } \\
\text { Neem (Azadirachtaindica),Nagchampa } \\
\text { (Calophylluminophyllum), Passion seed } \\
\text { (Passiflora edulis), Salmon oil, Tall } \\
\text { (Carnegiea gigantean), Croton megalocarpus, } \\
\text { Pachira glabra, Aleuritesmoluccana, } \\
\text { Terminalia belerica Jojoba } \\
\text { (Simmondsiachinensis), Rubber seed tree } \\
\text { (Hevcabrasiliensis) }\end{array}$ \\
\hline \begin{tabular}{|l|} 
Animal \\
Fats
\end{tabular} & $\begin{array}{l}\text { Fish oil, Beef tallow, Chicken fat Poultry fat, } \\
\text { Pork lard }\end{array}$ \\
\hline $\begin{array}{l}\text { Other } \\
\text { sources }\end{array}$ & $\begin{array}{l}\text { Algae (Cyanobacteria), Bacteria, Terpenes, } \\
\text { Poplar, Switchgrass, Fungi, Miscanthus, } \\
\text { Latexes, Microalgae (Chlorella Vulgaris), }\end{array}$ \\
\hline
\end{tabular}

TABLE 2. Current potential feed stocks for biodiesel worldwide $[1,11,15-19,39,44]$

\begin{tabular}{|l|l|}
\hline Country & Feed stocks \\
\hline Argentina & Soybean \\
\hline Brazil & Soybean/palm oil/castor/cotton oil \\
\hline Canada & $\begin{array}{l}\text { Rapeseed/animal fat/soybeans/yellow } \\
\text { grease and tallow/mustard/flax }\end{array}$ \\
\hline China & Jatropha/waste cooking oil/rapeseed \\
\hline France & Rapeseed/sunflower \\
\hline Greece & Cottonseed \\
\hline India & $\begin{array}{l}\text { Jatropha/PongamiaPinnata/Mahua } \\
\text { (Karanja)/soybean/rapeseed/sunflower/pe } \\
\text { anut }\end{array}$ \\
\hline
\end{tabular}

\begin{tabular}{|l|l|}
\hline Indonesia & Palm oil/Jatropha/coconut \\
\hline $\begin{array}{l}\text { New } \\
\text { Zealand }\end{array}$ & Waste cooking oil/tallow \\
\hline Spain & Linseed oil/sunflower \\
\hline USA & Soybeans/waste oil/peanut \\
\hline
\end{tabular}

\section{NON-EDIBLE FEED STOCKS}

Today, edible oil only can't be used as fuel in to days date to meet the huge demand of fuel due to various reasons. Under these circumstances, those feed stocks can be considered which produce oil insignificant quantity from non-edible oil feedstock and Following are few non-edible feed stocks . The edible oils like soybeans, palm oil, rapeseed, , coconut, and sunflower, which produces more than 90 percent of the planet's biodiesel. The plants of edible oils are well recognized in a lot of countries in the world such as USA, Germany, Australia, Malaysia, etc. At present, however, their use raises many apprehensions such as food versus fuel crisis. Furthermore, in the preceding 10 years the prices of vegetable oil plants have amplified radically which will influence the economic feasibility of biodiesel industry [17, 37]. The usage of biodiesel from edible feedstock is not favorable for long run because of the increasing gap of demand and supply of edible oils in numerous countries. The potential solutions to minimize the consumption of the edible oil for biodiesel purpose through utilizing non-edible oils. Non-edible oils feed stocks are gaining universal consideration because they are easily available around the world especially wasteland like forests, deserts, mountains, etc that are not suitable for edible crops, they eradicate competition for food, decline in deforestation rate, ecologically affable, and they are very inexpensive comparable to edible oils

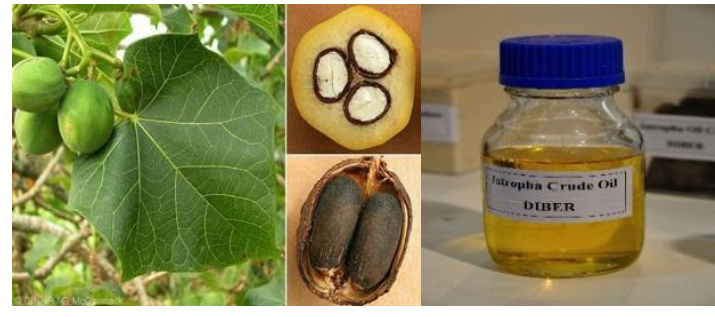

Jatropha curcas (Jatropha)

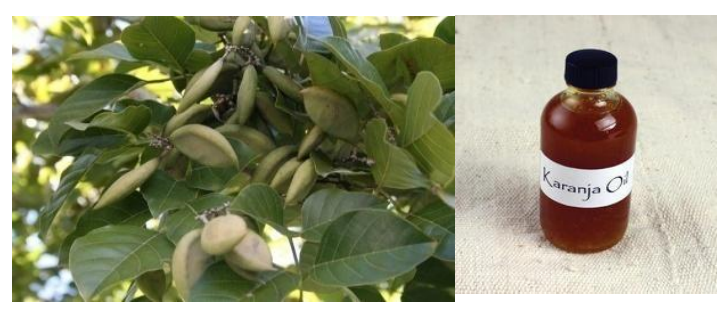

Pongamiapinnata (Karanja/ Honge)

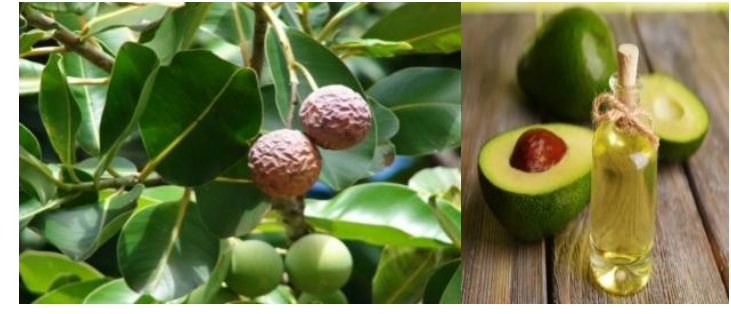

Calophylluminophyllum (Tamanu oil)

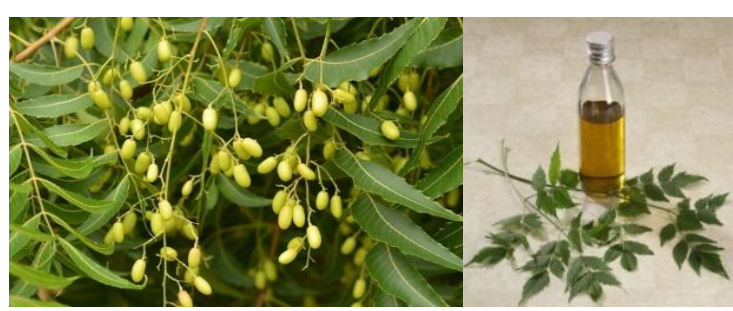

Azadirachtaindica (neem) 


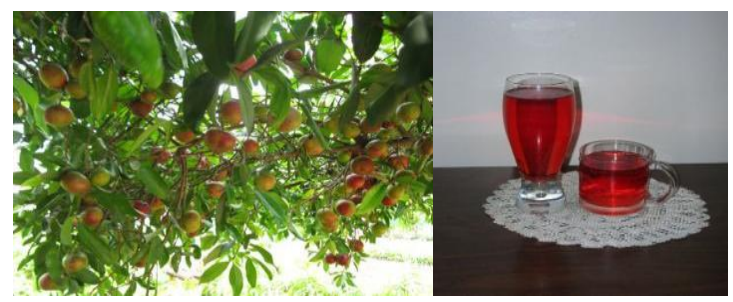

Garcinia indica seeds and oil

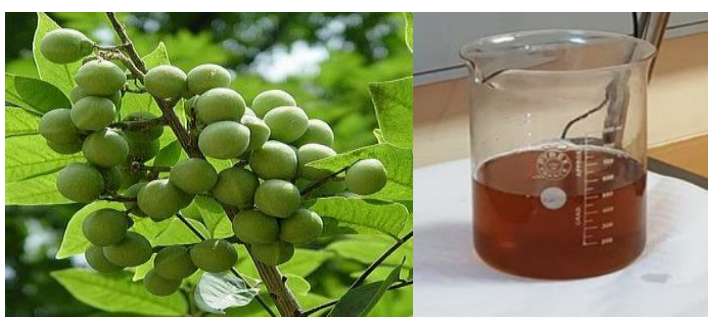

Sapindusmukorossi(Soap Nut)

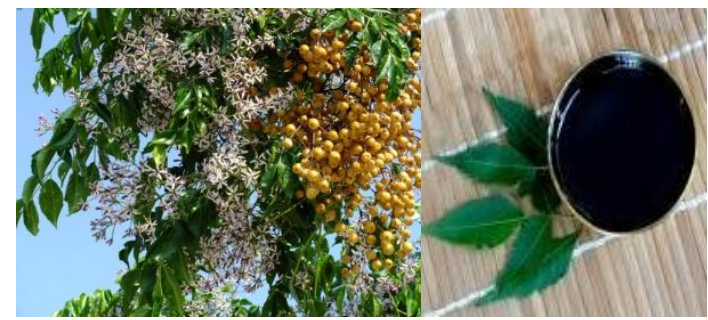

Melia azedarach (Chinaberry)

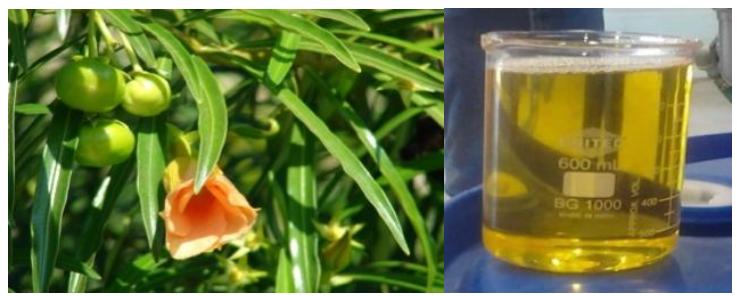

Thevetia peruviana (Yellow Oleander)
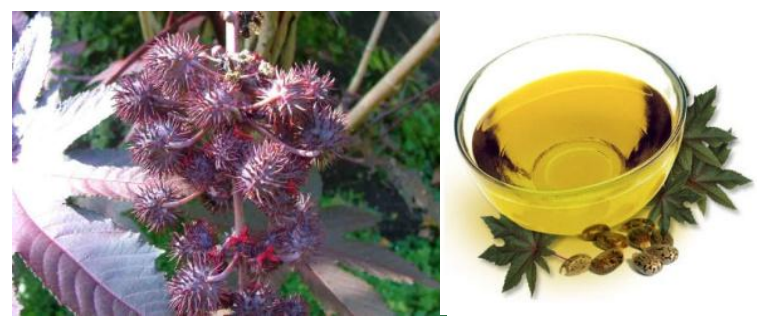

Ricinus Communis (Castor)
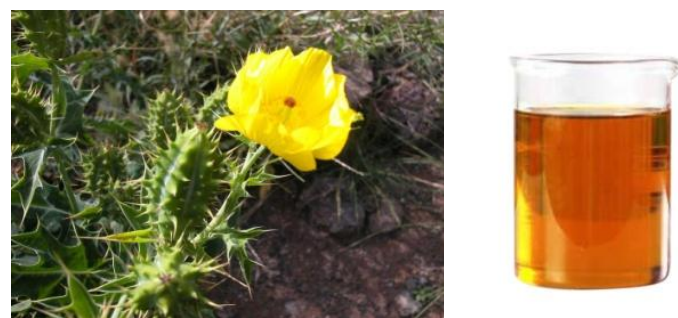

Argemone Mexicana (Mexican prickly poppy)

FIGURE 1. Main biodiesel Non-edible feed stocks [29,37,45]

\section{ENGINE PARAMETERS AND PERFORMANCE \& RESULTS}

The engine performance parameters related to biodiesel are mentioned below and the values for different feed stocks are explained in the Table 3

\section{Viscosity}

It affects the working of the fuel injection and spraying equipments. Kinematic viscosity of biodiesel is ten to fifteen times higher than diesel due larger molecular mass and its chemical structure. The maximum permissible limit according to ASTM D445, ranges are (1.9-6.0 $\left.\mathrm{mm}^{2} / \mathrm{s}\right)$ and $\left(3.5-5.0 \mathrm{~mm}^{2} / \mathrm{s}\right)[11,17,32,36]$.

Density is measured at the temperature range of 15 to 20oC according to EN ISO 3675/12185 and ASTM D1298 20 $\mathrm{C}$ [40].

\section{Relative density}

It is the density of the oil compared to the density of water. If a substance's relative density is less than one then it is less dense than the reference; if greater than 1 then it is denser than the reference. If the relative density is exactly 1 then the densities are equal; that is, equal volumes of the two substances have the same mass. The relative density of biodiesel is needed to make mass to volume conversions, calculate flow and viscosity properties, and is used to quantify the homogeneity of biodiesel tanks [29,41,43].

\section{Flashpoint}

Biodiesel has very high flashpoint that is near $150^{\circ} \mathrm{C}$ than conventional diesel fuel, which has a flash point of 55-66 ${ }^{\circ} \mathrm{C}[41]$.

ASTM D2500 EN ISO 23015 and D97 procedures are used to measure Cloud point and Flash point. [41,42]

\section{Cetane number $(C N)$}

Biodiesel observed higher cetane number as compared to diesel fuel [12].

\section{Oxidization stability}

The chemical composition of biodiesel helps fuels more vulnerable to oxidative degradation than fossil diesel fuel [9].

\section{Brake power Output (BP)}

The brake power of engines operating on pure plant oils or blends varies 10 to $-18 \%$ as compared to desiel engine. Variation results are due to higher viscosity during injection, which leads to poor atomization and also incomplete combustion; it also causes some plant oil to be left unburnt and enter in the engine crankcase which leads to absorption of power, plant having low calarofic value caused in reduction of cylinder pressure as compare to today's fossils fuel [43]. 


\section{BIODIESEL PRODUCTION UTILIZING DIVERSE SOURCES, CLASSIFICATION OF OILS AND THEIR ESTERS, PERFORMANCE AND EMISSION CHARACTERISTICS: A RESEARCH}

Brake specific fuel consumption (BSFC)

The BSFC of plant oil is the similar or superior to fossil diesel fuel $[30,43]$
Brake thermal efficiency (BTE)

Brake thermal efficiency is low due low volatility and High viscosity. [42, 43].

TABLE 3.Physiochemical properties of universally used biodiesel feed stocks [24,29,33-44]

\begin{tabular}{|c|c|c|c|c|c|c|c|c|c|c|}
\hline $\begin{array}{l}\text { Oil } \\
\text { or Fats }\end{array}$ & $\begin{array}{l}\text { Density } \\
15^{\circ} \mathrm{C} \\
\left(\mathrm{kg} / \mathrm{m}^{3}\right)\end{array}$ & $\begin{array}{l}\text { Kinetic } \\
\text { viscosity } \\
\text { at } 40^{\circ} \mathrm{C} \\
\left(\mathrm{mm}^{2} / \mathrm{s}\right)\end{array}$ & $\begin{array}{l}\text { Cetan } \\
\text { e No } \\
\left({ }^{\circ} \mathrm{C}\right)\end{array}$ & $\begin{array}{l}\text { Flash } \\
\text { Point } \\
\left({ }^{\circ} \mathrm{C}\right)\end{array}$ & $\begin{array}{l}\text { High } \\
\text { heating } \\
\text { value } \\
(\mathrm{MJ} / \mathrm{kg})\end{array}$ & $\begin{array}{l}\text { Cloud } \\
\text { point } \\
\left({ }^{\circ} \mathrm{C}\right)\end{array}$ & $\begin{array}{l}\text { Calorific } \\
\text { value } \\
\text { MJ/kg }\end{array}$ & $\begin{array}{l}\text { Pour } \\
\text { point } \\
\left({ }^{\circ} \mathrm{C}\right)\end{array}$ & $\begin{array}{l}\text { Iodine } \\
\text { No } \\
\left({ }^{\circ} \mathrm{C}\right)\end{array}$ & $\begin{array}{l}\text { Acid } \\
\text { (neutral } \\
\text { ization) } \\
\text { value } \\
\text { (mg } \\
\text { KOH/g) }\end{array}$ \\
\hline Canola & - & 4.42 & 37.6 & 160 & 39.7 & -3.3 & - & -9 & - & 0.01 \\
\hline Soybean & 913.8 & 4.039 & 37.9 & 254 & 39.6 & 0.9 & 39.76 & - & $\begin{array}{l}128- \\
143\end{array}$ & 0.266 \\
\hline Sunflower & 880 & 4.439 & 49 & 160 & 39.6 & 3.4 & - & - & - & 0.027 \\
\hline Palm & 864.42 & 4.5 & 54.6 & 135 & - & 16 & - & 15 & 54 & 0.24 \\
\hline Peanut & 848 & 4.42 & 53.59 & 166 & 39.8 & 0 & 40.1 & -8 & 67.45 & 0.28 \\
\hline Safflower & 885.5 & 5.8 & 56 & 148 & - & -5 & 38.122 & - & - & - \\
\hline Mesua & 898 & 6.2 & 54 & 112 & 39.5 & - & 42.23 & 3 & - & 0.01 \\
\hline Rice Bran & 872 & 4.811 & 51.6 & 430 & - & - & 41.38 & 269 & - & 0.48 \\
\hline Maclura & 889 & 4.66 & 48 & 180 & 39.4 & -5 & - & -9 & 125 & 0.4 \\
\hline $\begin{array}{l}\text { Cotton } \\
\text { seeds }\end{array}$ & 875.7 & 4.09 & 51.43 & 150 & 39.4 & 7 & 40.43 & 6 & - & 0.16 \\
\hline Jatropha & 879.5 & 4.8 & 51.6 & 135 & 38.65 & 2.7 & 39.23 & 2 & 104 & 0.4 \\
\hline Neem & 868 & 5.213 & - & 76 & - & 9 & 39.81 & 2 & - & 0.649 \\
\hline Karanja & 931 & 6.13 & 55 & 95 & - & 7 & 43.42 & 3 & - & 0.42 \\
\hline Mahua & 874 & 3.98 & 65 & 208 & 36.0 & - & 36.8 & 6 & - & 0.41 \\
\hline Linseed & 874 & 3.752 & 52 & 160 & 39.3 & -3.8 & - & -15 & - & 0.058 \\
\hline Coconut & 807.3 & 2.726 & - & 114.8 & - & - & - & - & - & 0.106 \\
\hline Rapeseed & 882 & 4.43 & 54.4 & 170 & 37.4 & -3.3 & 37 & -12 & - & - \\
\hline Tobacco & 888.5 & 4.23 & 51.6 & 165.4 & - & - & - & - & 136 & 0.3 \\
\hline Beef tallow & - & 4.624 & - & - & - & - & - & - & - & 0.147 \\
\hline Roselle & 880.1 & 4.588 & - & 130 & - & - & - & -1 & 62 & 0.43 \\
\hline Okra & 876 & 4.01 & 55.2 & 156 & - & 1.10 & - & 2.12 & - & 0.38 \\
\hline Rubber & - & 5.81 & - & 130 & - & 4 & 36.5 & -8 & - & - \\
\hline Coffee & - & 4.852 & - & 160 & - & 0.2 & - & - & - & 0.076 \\
\hline Diesel & 850 & $1.3-4.1$ & $40-55$ & $60-80$ & 42 & -20 & $42-46$ & -35 & 38.3 & 0.062 \\
\hline $\begin{array}{l}\text { Calophyll- } \\
\text { um } \\
\text { Inaphyllu- } \\
\text { m }\end{array}$ & 888.6 & 7.72 & 51.9 & 151 & - & 38 & - & - & 85 & 0.76 \\
\hline
\end{tabular}

\section{Biodiesel production technologies}

The methodologies for biodiesel production are transesterification, pyrolysis and micro-emulsion. Worldwide, many researchers are developing and improving vegetable oil properties in order to estimate the properties of diesel fuels. The low volatility, high viscosity, and polyunsaturated characters are the common problems associated problems with crude vegetable oils and the problems can be overcome by the above mentioned process $[1,6,11,12,16,22,44,47]$. 


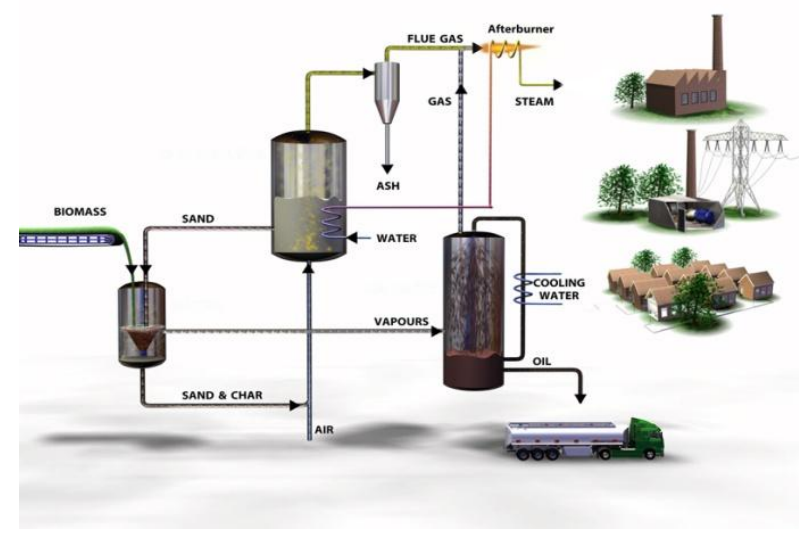

FIGURE 2. Pyrolysis [49]

\section{Transesterification}

One of the best suitable method for production of biodiesel is the Transesterification, it is considered as the unsurpassed method among other methods due to its economic viability and plainness. Transesterification process follows a number of successive, reversible reactions, the detailed process is shown in Fig. 3. The triglycerides are converted first into diglycerides, then monoglyceride and finally into glycerol the glycerol is the by-product which settles down at the bottom, which is used as feedstock in the cosmetic industry and biodiesel is extracted and washed which floats on top, The two main light alcohols used are methanol and ethanol used for transesterification process due to their moderately low cost. $[9,11,22,42,44,46]$

\section{Micro-emulsion}

Micro-emulsion is the colloidal equilibrium dispersion of optically isotropic fluid microstructure with dimensions generally into $1-150 \mathrm{~nm}$ range formed spontaneously from two immiscible liquids and one and more ionic or more ionic amphiphiles. Many researchers have been worked on Micro-emulsions using solvents such as butanol, 1-butanol hexanol, ethanol, and methanol. With these solvents caused increase in viscosity need for diesel fuel. [11,44]

\section{Pyrolysis}

The thermal decomposition of the organic matters in the absence of air and in the presence of a catalyst is known as Pyrolysis. The detailed process is shown in Fig. 2. The decomposing material can be vegetable oils, natural fatty acids, animal fats or methyl esters of fatty acids. Many researcher have studied the pyrolysis of triglycerides to get suitable fuels for diesel engine. Thermal decomposition of triglycerides produces carboxylic acids, alkadines, aromatics, alkanes and alkenes. Pyrolysis process is pollution free, very effective with less effort . [11,33,42,44]

\section{Dilution}

Generally, vegetable oils are mixed and diluted with diesel to decrease the viscosity and progress the performance of engine. This method does not need any chemical reaction $[17,44]$. Singh,. et al. reported a blend

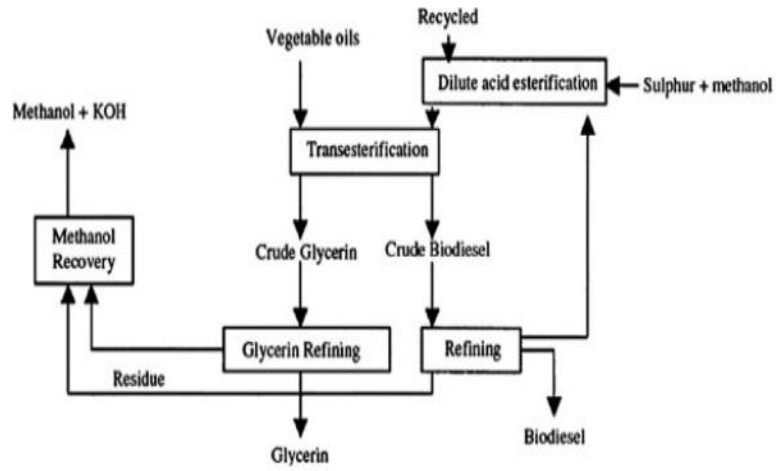

\section{FIGURE 3.Transesterification [48]}

of $20 \%$ vegetable oil and $80 \%$ diesel fuel was successful rather in diesel engines rather than $100 \%$ vegetable oil [11]. Dilution usually consists of the use of blends of diesel fuel with waste cooking oil, African pear seed, coconut oil, oil rubber seed oil, sunflower oil, palm oil, cottonseed oil, soybean oil, rice bran, rapeseed oil and many more. For instance, $25 \%$ of sunflower oil mixed with $75 \%$ of diesel fuel (in ratio of $25: 75$ ) or B25 in a direct injection diesel engine was investigated [95]. The authors observed that this mixture was not adaptable for long-standing use in direct injection engines. The maximum prescribed viscosity value according to ASTM is $4.0 \mathrm{cSt}$ at $313 \mathrm{~K}$, but it exceeded that. [44,47].

\section{BIODIESEL EMISSSIONS}

Biodiesel fuel is the solelynon-conventional fuel to have efficiently completed the Health Effects Testing requirements of the Clean Air Act (1990).

Almost 50 percent particulate emissions is reduced as contrast with fossil fuelled diesel. Having a superior cetane rating than petro-diesel, some optimistic effects of biodiesel fuel on atmosphere can be seen as it can progress performance and reduce emissions. The data from EIA, US Energy and Administration suggests biodiesel is derived from the plants that are the sources of the feed stocks . Biodiesel is considered a carbon neutral product because the $\mathrm{CO}_{2}$ is absorbed by the plants such as soybeans and palm oil trees while making and burning biodiesels. Biodiesel reduces the emission of Carbon Monoxide (CO), Nitrogen Oxide $\left(\mathrm{NO}_{\mathrm{X}}\right)$, unburned Hydrocarbons (HC) $[1,4,27,30,43]$. Fig 4 describes the basic emissions effects, overall the emissions percentages are lower compared with the diesel fuel. However while using biodiesel the engine output power and mechanical efficiency were reduced and fuel consumption was increased [15]. A number of researchers worked in blending the oil feed stocks and used mixture of diesel fuel to enhance the properties of biodiesel [16-20]. S. Senthilkumar., etal. and Jalpit B. Prajapati,.et al. observed the biodiesel mixing (B5, B10 and B15) results in decrease in fuel consumption,carbon di oxide, carbon monoxide and Hydrocarbon emission as contrasted with 


\section{BIODIESEL PRODUCTION UTILIZING DIVERSE SOURCES, CLASSIFICATION OF OILS AND THEIR ESTERS, PERFORMANCE AND EMISSION CHARACTERISTICS: A RESEARCH}

diesel fuel. In four stock desiel engine were tested using palm biodiesel as Pyrolysis. The detailed process is shown in Fig. 2. The decomposing material can be vegetable oils, natural fatty acids, animal fats or methyl esters of fatty acids. Many researcher have studied the pyrolysis of triglycerides to get suitable fuels for diesel engine. Thermal decomposition of triglycerides produces carboxylic acids, alkadines, aromatics, alkanes and alkenes. Pyrolysis process is pollution free, very effective with less effort . [11,33,42,44]

\section{Dilution}

Generally, vegetable oils are mixed and diluted with diesel to decrease the viscosity and progress the performance of engine. This method does not need any chemical reaction $[17,44]$. Singh,. et al. reported a blend of $20 \%$ vegetable oil and $80 \%$ diesel fuel was successful rather in diesel engines rather than $100 \%$ vegetable oil [11]. Dilution usually consists of the use of blends of diesel fuel with waste cooking oil, African pear seed, coconut oil, oil rubber seed oil, sunflower oil, palm oil, cottonseed oil, soybean oil, rice bran, rapeseed oil and many more. For instance, $25 \%$ of sunflower oil mixed with $75 \%$ of diesel fuel (in ratio of $25: 75$ ) or B25 in a direct injection diesel engine was investigated [95]. The authors observed that this mixture was not adaptable for long-standing use in direct injection engines. The maximum prescribed viscosity value according to ASTM is $4.0 \mathrm{cSt}$ at $313 \mathrm{~K}$, but it exceeded that. [44,47]. fuel instead of Diesel, testes result showed that at lower load smoke capacity higher and vice versa as compared to diesel oil and also in exhaust gaseous $46 \%$ reduction in carbon monoxide were observed [54]. Numerous studies demonstrated that with increase in palm biodiesel-diesel blends percentage leads increase in $\mathrm{NO}_{\mathrm{X}}$ emissions and reduce in $\mathrm{CO}$ and $\mathrm{HC}$ emissions [30].

Increasing in engine brake power result in decreased of $\mathrm{CO}$ emissions. Fig. 6 suggests the effect of soybean, rapeseed and animal tallow biodiesels, the percentage of emission for $\mathrm{CO}$ was lower for animal fat compared to soybean and rapeseed. The experimentation conducted by M.S. Gad et. al using the blends B20, B100 and PO20 demonstrated, due to good quantity of oxygen molecules and lower proportion of carbon content in biodiesel blends as compared to that of diesel fuel which helps in good combustion and as result reduction in carbon monoxide emission. The presence of oxygen in the molecular structure of biodiesel are one of reason for better combustion. [53, 54]

Since biodiesel is having higher oxygen content than diesel fuel, $\mathrm{NO}_{\mathrm{X}}$ emissions behaves proportional to percentage of biodiesel and oil in biodiesel and oil blends. Fig. 5 suggests the effect of soybean, rapeseed and animal tallow biodiesels, the percentage of $\mathrm{NO}_{\mathrm{X}}$ was higher for animal fat compared to soybean Zeldovich,. et al. cited

For all testing condition observed that with increase in engine load, $\mathrm{NO}_{\mathrm{X}}$ emissions increased, as result temperature of cylinder also increased which also became responsible for Higher $\mathrm{NO}_{\mathrm{X}}$ formation an d emission with addition to presence of oxygen[ $30,43,54]$. Resulting oxygen content increased with mixing of biodiesel to diesel which lead to better combustion as result hydrocarbon emission are lowered .Emprovement in proportion of oxygen leads to reduction in hydrocarbon emission which can also be attributed to cetane [55]. Fig. 5 represents the effect of soybean or rapeseed and animal tallow biodiesels, the percentage of emission for Particulate Matters (PM) was lower for animal fat compared to soybean. Overall the PM will reduce using the biodiesel ascompared to the diesel fuel.

\section{Greenhouse Gas (GHG) emissions}

Biodiesel having capacity to decrease greenhouse emission as compared to fossils fuel based on various factor. Carbon Di oxide is one of the main green house gas which involve in nurture of all green plants. When it turned to biodiesel from biomass, used to run engine as result entire GHG emission will be occurred. Pretentious to today's production methods, with no land use change, biodiesel from sunflower and rapeseed oil produce $45 \%$ $65 \%$ lower GHG emissions than petro-diesel. But calculation of carbon intensity of biodiesel fuels is a difficult and also inaccurate. Nevertheless, there is ongoing research for improving the effectiveness of the production process of the biodiesel.

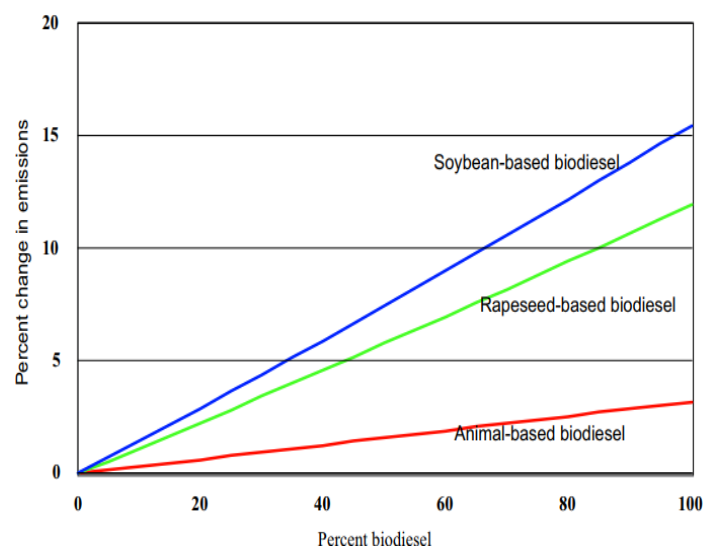

FIGURE 4. Basic emissions effects [56,57]

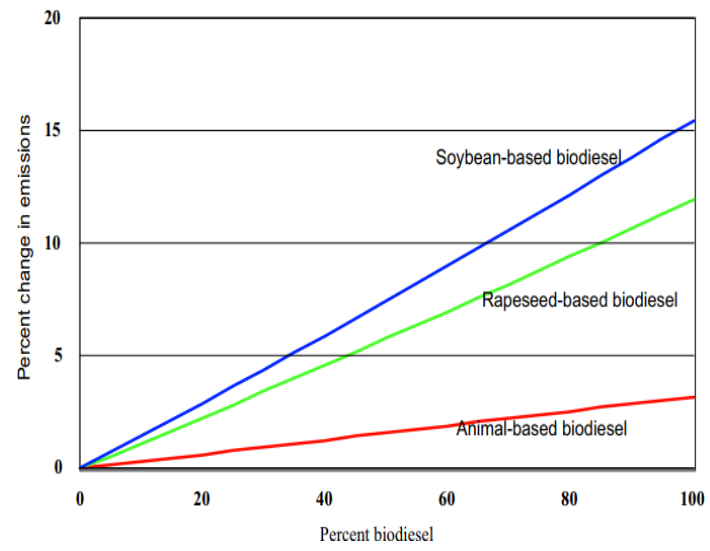

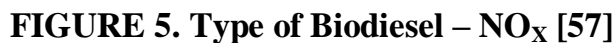




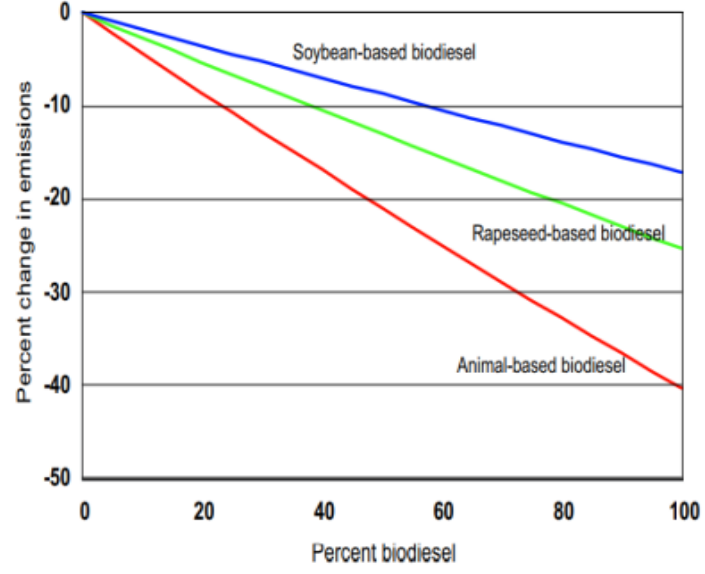

FIGURE 6. Type of Biodiesel - CO[56]

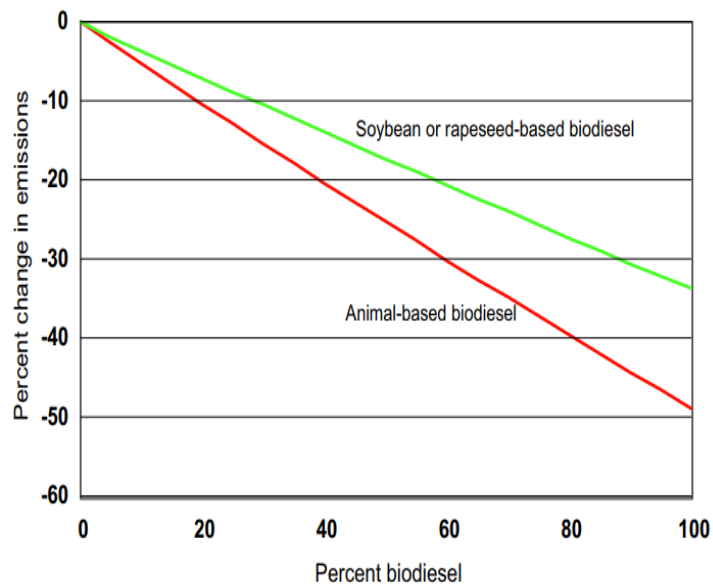

FIGURE 7. Type of Biodiesel - PM[57]

As Biodiesel burns clean, this suggests there will be a major decline an all sort of pollutants adding to smog and global warming. It is the only non-conventional fuel which has been standardized and approved by the Environmental Protection Agency (EPA). In addition, it has conceded every Heath-Effects Test of the Clean Air Act and fulfils the requirements of the California Air Resources Board (CARB).

\section{REFERENCES}

1. Basha, Syed Ameer, K. Raja Gopal, and S. Jebaraj. "A review on biodiesel production, combustion, emissions and performance." Renewable and sustainable energy reviews 13.6 (2009): 1628-1634.

2. Canoira, Laureano, et al. "Biodiesel from Jojoba oil-wax: Transesterification with methanol and properties as a fuel." Biomass and Bioenergy 30.1 (2006): 76-81.

3. Demirbas A. Biodiesel production via non-catalytic SCF method and biodiesel Fuel characteristics. Energy Convers Manage 2006; 47:2271-82.

4. Rakopoulos CD. Comparative performance and emission studies when using Olive oil as a fuel supplement in DI and IDI diesel engines. Renew Energy 1992; 2:327-31.

5. Keskin A, Gürü M, Altıparmak D, Aydın K. Using cotton oil biodiesel-diesel Fuelblends with alternative diesel fuel. Renew Energy 2008; 33:553-7.

6. Sharma YC, Singh B, Upadhyay SN. Advancements in development and characterization of biodiesel: a review. Fuel 2008; 87:2355-73

7. Dias JM, Maria CM, Ferraz A, Almeida MF. Comparison of the performance of different homogeneous alkali catalysts during transesterification of waste and virgin oils and evaluation of biodiesel quality. Fuel 2008; 87:3572-8.

8. Dmytryshyn SL, Dalai AK, Chaudhari ST, Mishra HK, Reaney MJ. Synthesis andCharacterization of vegetable oil derived esters: evaluation for their diesel Additive properties. Bioresour Technol 2004; 9:55-64.

9. Shahid EM, Jamal J. Production of biodiesel: a technical review. Renew Sustain Energy Rev 2011; 15(9):4732-45.

10. Kafuku G, Mbarawa M. Biodiesel production from Croton megalocarpus oil and it's process optimization. Fuel 2010; 89:2556-

11. Singh SP, Singh D. Biodiesel production through the use of different sources and characterization of oils and their esters as the substitute of diesel: a Review. Renew Sustain Energy Rev 2010; 14(1):200-16.

12. Karmakar A, Karmakar S, Mukherjee S. Properties of various plants and animals feed stocks for biodiesel production. Bioresour Technol 2010; 101(19):7201-10

13. Lin L, Kunshan Z, Vittayapadung S, Xiangqi S, Mingdong D. Opportunities and challenges for biodiesel fuel. Appl Energy 2011; 88(4):1020-31.

14. Kibazohi O, Sangwan RS. Vegetable oil production potential from Jatropha Curcas, Croton megalocarpus, Aleuritesmoluccana, Moringa oleifera and Pachiraglabra: assessment of renewable energy resources for bio-energy production in Africa. Biomass Bioenergy 2011; 35(3):1352-6.

15. Sharma YC, Singh B. Development of biodiesel: current scenario. Renew Sustain Energy Rev 2009; 13(6-7):164651 .

16. Ahmad AL, Mat Yasin NH, Derek CJC, Lim JK. Microalgae as a sustainable Energy source for biodiesel production: a review. Renew Sustain Energy Rev 2011; 15(1):584-93

17. Balat $\mathrm{M}$, Balat H. Progress in biodiesel processing. Appl Energy 2010; 87(6):1815-35.

18. Biswas, Pradip Kumar, Sanjib Pohit, and Rajesh Kumar. "Biodiesel from jatropha: can India meet the $20 \%$ blending target?." Energy policy 38.3 (2010): 1477-1484.

19. Azam MM, WarisA,NaharNM.Prospects and potential of fatty acid methyl esters of some non-traditional seed oils for use as biodiesel in India. Biomass and Bioenergy2005; 29(4):293-302.

20. KibazohiO, Sangwan RS.Vegetable oil production potential from Jatropha curcas, Croton megalocarpus, Aleuritesmoluccana, Moringa oleifera and Pachira glabra: assessment of renewable energy resources for bio-energy production in Africa. Biomass and Bioenergy2011;35(3):1352-6.

21. Sahoo PK, Das LM, Babu M K G, NaikSN.Biodiesel development from high acid value polanga seed oil and performance valuation in a CI engine.Fuel 2007;86(3):448-54.

22. Pinzi S, Garcia IL, Gimenez F JL, Castro MDL, Dorado G, Dorado M P.The ideal Vegetable oil-based biodiesel composition :a review of social, economical and technical implications. Energy \& Fuels 2009;23:2325-41.

23. Scott PT, Pregelj LC, Ning H, Johanna SD, Michael AG, Peter M. Pongamiapinnata: an untapped resource for the biofuels industryof the future. Bioenergy Res2008;1(1):211.

24. Naik, Malaya, et al. "Production of biodiesel from high free fatty acid Karanja (Pongamiapinnata) oil." Biomass and Bioenergy 32.4 (2008): 354-357.

25. Karmee, Sanjib Kumar, and Anju Chadha. "Preparation of biodiesel from crude oil of Pongamiapinnata." Bioresource technology 96.13 (2005): 1425-1429.

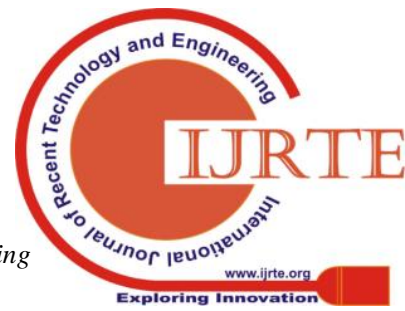




\section{BIODIESEL PRODUCTION UTILIZING DIVERSE SOURCES, CLASSIFICATION OF OILS AND THEIR ESTERS, PERFORMANCE AND EMISSION CHARACTERISTICS: A RESEARCH}

26. Ghadge SV,Raheman Hifjur. Biodiesel production from mahua (Madhucaindica) oil having high free fatty acids. Biomass Bioenergy 2005; 28(6): 601-5.

27. Puhan SV, Ram N, Boppana VB, Sankarnarayanan G, Jeychandran K. Mahua oil (Madhuca Indica seed oil) methyl ester as biodiesel-preparation and emission characterstics.Biomass Bioenergy2005;28(1):87-93.

28. Muthu H,Sathya Selvabala V,Varathachary TK,Kirupha SD,Nandagopa LJ, Subramanian S. Synthesis of biodiesel from Neem oil using sulfated zirconia via tranesterification. BrazJChemEng 2010; 27(4):601-8.

29. Kumar A, Sharma S. Potential non-edible oil resources as biodiesel feedstock: an Indian perspective. RenewSustain Energy Rev2011;15(4):1791-800.

30. Nabi MN,Akhter MS,Zaglul SMM. Improvement of engine emissions with Conventional diesel fuel and dieselbiodiesel blends. Bioresour Technol 2006;97(3):372-8.

31. HosamaniKM,Hiremath VB, Keri RS. Renewable energy sources from Micheliachampaca and Garcinia indica seed oils:a rich source of oil. Biomass Bioenergy 2009; 33(2):267-70.

32. Rabe ELM. Jatropha oil in compression ignition engines, effects on the engine, Environment and Tanzania as supplying country. Eindhoven: Eindhoven University of Technology; 2010.

33. Atadashi IM, Aroua MK, Abdul Aziz A. High quality biodiesel and its diesel engine application: a review. Renew Sustain Energy Rev 2010;14(7):1999-2008.

34. Karmakar A, Karmakar S, Mukherjee S. Properties of various plants and animals feed stocks for biodiesel production. Bioresour Technol 2010; 101(19):7201-10.

35. Srivastava A, Prasad R. Triglycerides-based diesel fuels. Renew Sustain Energy Rev 2000;4(2):111-33.

36. Balat M. Potential alternatives to edible oils for biodiesel production- a review of current work. Energy Convers Manage 2011; 52(2): 1479-92.

37. Gui MM, Lee KT, Bhatia S. Feasibility of edible oil vs. non-edible oil vs. waste edible oil as biodiesel feedstock. Energy 2008;33(11):1646-53.

38. Sarin R, Sharma M, Sinharay S, Malhotra RK. JatrophaPalm biodiesel blends: an optimum mix for Asia. Fuel 2007;86(10-11):1365-71.

39. Demirbas A. Relationships derived from physical properties of vegetable oil and biodiesel fuels. Fuel 2008; 87(8-9):1743-8.

40. Torres-Jimenez E, Jerman MS, Gregorc A, Lisec I, Dorado M, Kegl B. Physical and chemical properties of ethanoldiesel fuel blends. Fuel 2011;90(2):795-802

41. Sanford, S. D., White, J. M., Shah, P. S., Wee, C., Valverde, M. A., \& Meier, G. R. (2009). Feedstock and biodiesel characteristics report. Renewable Energy Group, $416,1-136$

42. Demirbas A. Biodiesel production from vegetable oils by supercritical methanol. J SciInd Res 2005;64:858-65.

43. Purushothaman, K., and G. Nagarajan. "Performance, emission and combustion characteristics of a compression ignition engine operating on neat orange oil." Renewable Energy 34.1 (2009): 242-245.

44. Atabani, A. E., Silitonga, A. S., Badruddin, I. A., Mahlia, T. M. I., Masjuki, H. H., \&Mekhilef, S. (2012). A comprehensive review on biodiesel as an alternative energy resource and its characteristics. Renewable and sustainable energy reviews, 16(4), 2070-2093.

45. Friday, J. B., \& Okano, D. (2006). Calophylluminophyllum (kamani). Species profiles for Pacific Island agroforestry, 2(1), 1-17.

46. Soudagar, Manzoor Elahi M., et al. "Production of Mahua Oil Ethyl Ester (MOEE) and its Performance test on four stroke single cylinder VCR engine." IOP Conference Series: Materials Science and Engineering. Vol. 225. No. 1. IOP Publishing, 2017.
47. Parawira W. Biodiesel production from Jatropha curcas: a review. Sci Res Essays 2010;5(14):1796-808.

48. Musa, Idris Atadashi. "The effects of alcohol to oil molar ratios and the type of alcohol on biodiesel production using transesterification process." Egyptian Journal of Petroleum 25.1 (2016): 21-31.

49. Biomass technology group, Available online: http://www.btgworld.com/en/rtd/technologies/fastpyrolysis [cited: 26.11.17]

50. Khan, TM Yunus, et al. "Ceiba pentandra, Nigella sativa and their blend as prospective feed stocks for biodiesel." Industrial Crops and Products 65 (2015): 367-373.

51. ASTM standardization, "standards for biodiesel"/ASTM Newsletters 2014-2016.

52. Agarwal D, Kumar L, Agarwal AK. Performance evaluation of a vegetable oil fuelled compression ignition engine. Renew Energy 2008;33:1147-56.

53. Senthilkumar, S., G. Sivakumar, and Siddarth Manoharan. "Investigation of palm methyl-ester bio-diesel with additive on performance and emission characteristics of a diesel engine under 8-mode testing cycle." Alexandria Engineering Journal 54.3 (2015): 423-428.

54. Gad, M. S., et al. "Performance and emissions characteristics of $\mathrm{CI}$ engine fueled with palm oil/palm oil methyl ester blended with diesel fuel." Egyptian Journal of Petroleum (2017).

55. Rahman, SM Ashrafur, et al. "Production of palm and Calophylluminophyllum based biodiesel and investigation of blend performance and exhaust emission in an unmodified diesel engine at high idling conditions." Energy Conversion and Management 76 (2013): 362-367.

56. United States Environmental Protection Agency,Available online: https://www.epa.gov/air-emissions-inventories/airemissions-sources [cited: 26.11.17]

57. International Environmental Agency, Available online: http://www.ieaamf.org/content/fuel_information/fatty_acid _esters/emissions [cited: 26.11.17]

58. Soudagar, Manzoore Elahi M., et al. "The effect of nanoadditives in diesel-biodiesel fuel blends: A comprehensive review on stability, engine performance and emission characteristics." Energy Conversion and Management 178 (2018): 146-177.

59. Soudagar, Manzoor Elahi M., et al. "Production of Mahua Oil Ethyl Ester (MOEE) and its Performance test on four stroke single cylinder VCR engine." IOP Conference Series: Materials Science and Engineering. Vol. 225. No. 1. IOP Publishing, 2017. 